\title{
PERKEMBANGAN KAJIAN KOMUNIKASI PEMASARAN DI KOTA MALANG : SEBUAH META ANALISIS
}

\author{
Rezki Rahmawati, Antoni, Bambang Dwi Prasetyo \\ Program Studi S2 Ilmu Komunikasi FISIP Universitas Brawijaya \\ kikimustari@gmail.com
}

\begin{abstract}
This research is a meta-analysis of the development of the study of marketing communication undergraduate thesis in Malang during 2014-2018. This research aims to find out how the development of marketing communication studies with the philosophy of science approach in order to provide references for mapping marketing communication studies. The undergraduate thesis researched in this research is 229 theses from three different universities with a focus on the use of theory in marketing communication theses. The results of the research show that the most widely used communication theory in marketing communication thesis is the Elaboration Likelihood Model (ELM) theory. The interesting thing found in this research is the more use of marketing concepts and theories than the use of communication theory in undergraduate thesis with the theme of marketing communication.
\end{abstract}

Keywords: marketing communication, meta-analysis, philosophy of science

\section{Abstrak}

Penelitian ini merupakan penelitian meta analisis terhadap perkembangan kajian skripsi komunikasi pemasaran di Kota Malang tahun 2014-2018. Penelitian ini bertujuan mengetahui bagaimana perkembangan kajian komunikasi pemasaran dengan pendekatan filsafat ilmu sehingga dapat menjadi referensi untuk memetakan kajian komunikasi pemasaran. Skripsi yang diteliti dalam penelitian ini sebanyak 229 skripsi dari tiga universitas berbeda dengan fokus penggunaan teori dalam skripsi komunikasi pemasaran. Hasil penelitian menunjukkan bahwa teori komunikasi yang paling banyak digunakan dalam skripsi komunikasi pemasaran adalah teori Elaboration Likelihood Model (ELM). Hal yang menarik yang ditemukan dalam penelitian ini adalah lebih banyaknya penggunaan konsep dan teori pemasaran daripada penggunaan teori komunikasi dalam skripsi dengan tema komunikasi pemasaran.

Kata Kunci: komunikasi pemasaran, meta analisis, filsafat ilmu

\section{PENDAHULUAN}

Perkembangan komunikasi pemasaran sebagai sebuah kajian pertama kali diperkenalkan oleh Butler dari University Of Chicago yang mengadopsi pemasaran dari riset-riset penjualan pada tahun 1906 ke dalam ilmu komunikasi. Butler mengambil istilah tersebut dari kajian ilmu ekonomi dan dari pemikirian teoritik
Ricardo dan Adam Smith. Pada perkembangannya, semenjak tahun 1946 pemasaran dianggap lebih luas, tidak hanya menyangkut unsur-unsur penjualan saja. Maka kemudian mulailah masuk berbagai unsur di dalamnya (Prisgunanto, 2006).

Harsono Suwardi menyatakan bahwa dasar dari pemasaran adalah 
komunikasi. Pemasaran dapat menjadi sangat powerful jika dipadukan dengan komunikasi yang efektif dan efisien. Bagaimana menarik konsumen atau khalayak menjadi aware, kenal dan mau membeli suatu produk atau jasa lewat saluran komunikasi adalah bukan sesuatu yang mudah (Kennedy \& Soemanagara, 2006). Sejalan dengan Harsono (dalam Kennedy \& Soemanagara, 2006), Tjiptono (2008) mendefinisikan komunikasi pemasaran sebagai sebuah kegiatan dalam pemasaran yang bertujuan untuk menyebarkan informasi, memengaruhi atau membujuk, dan mengingatkan pasar sasaran atas perusahaan dan produknya agar masyarakat dapat menerima, membeli, dan loyal pada produk yang ditawarkan oleh perusahaan yang bersangkutan. Bahkan menurut Tjiptono (2008), ada tiga unsur pokok dalam proses komunikasi pemasaran, yaitu pelaku komunikasi, material komunikasi, dan proses komunikasi. Ketiganya merupakan mata rantai yang tidak bisa terpisahkan satu sama lainnya.

Melihat banyaknya kajian komunikasi pemasaran yang sering dipelajari oleh mahasiswa ilmu komunikasi pada minat konsentransi komunikasi bisnis atau manajemen komunikasi diberbagai universitas yang menyelenggarakan pendidikan ilmu komunikasi, perlu adanya sebuah kajian yang fokus terhadap perkembangan keilmuan komunikasi pemasaran itu sendiri dengan melihat secara khusus kajian literatur yang digunakan dalam penelitian-penelitian komunikasi pemasaran. Salah satu metode yang dapat digunakan untuk memetakan kajian komunikasi pemasaran adalah meta analisis.
Penelitian ini akan menggunakan meta analisis tematik untuk mengetahui kecenderungan dan pola-pola perkembangan kajian komunikasi pemasaran. Penelitian meta analasis kajian komunikasi pemasaran yang dilakukan dalam penelitian ini akan menggunakan pendekatan filsafat komunikasi sebagai penerapannya. Titik awal dari semua teori adalah asumsi-asumsi filsafat yang mendasarinya (Littlejohn \& Foss, 2012). Asumsi-asumsi yang digunakan oleh seorang ahli teori menggambarkan bagamana kegunaan dari adanya teori tersebut. Asumsi-asumsi filsafat dibagi menjadi tiga, antara lain epistemologi, ontologi, dan aksiologi.

Penelitian ini lebih berada dalam tataran asumsi epistemologi yang merupakan cabang filsafat dalam mempelajari pengetahuan atau bagaimana orang-orang mengetahui apa yan mereka ketahui (Littlejohn \& Foss, 2012).

Objek penelitian dalam penelitian ini adalah skripsi mahasiswa komunikasi manajemen di tiga universitas di Kota Malang. Skripsi dipilih menjadi objek karena penelitian merupakan tolak ukur perkembangan suatu kajian (Kriyantono, 2014). Ketiga universitas tersebut di antaranya, Universitas Brawijaya, Universitas Muhammadiyah Malang, dan Universitas Merdeka Malang.

\section{Kajian Filsafat Ilmu dalam Studi Komunikasi}

Filsafat dalam komunikasi sendiri diartikan oleh Effendy (2003)sebagai suatu disiplin yang menelaah 
pemahaman (verstehen) secara fundamental, metodologis, sistematis, analitis, kritis, dan holostik teori dari proses komunikasi yang meliputi segala dimensi menurut bidang, tatanan, tujuan, fungsi teknik dan metodenya.

Richard Lanigan (dalam Effendy, 2003) menerangkan filsafat sebagai disiplin yang biasanya dikategorikan sebagai sub-bidang utama menurut justifikasinya terhadap penyelidikan sistematis pada metafisika, epistimologi, aksiologi, dan logika.

filsafat komunikasi diartikan oleh Arneson (2007) sebagai sebuah seni penalaran yang memungkinkan lahirnya pemahaman inovatif dari reproduksi atau representasional akan pemahaman komunikasi di era post modern. Adanya filsafat komunikasi memungkinkan kita untuk mengetahui pemikiran filosifis mengenai cara manusia berkomunikasi yang pada realitasnya sangat dipengaruhi oleh dunia sekitarnya.

Dalam penelitian ini peneliti dituntut untuk berpikir secara epistemologis dalam paradigma interpertratif. Aspek espistemologis adalah kebenaran fakta atas sudut pandang bagaimana dan mengapa fakta tersebut adalah benar dan dapat diverifikasi serta dibuktikan kebenarannya.

\section{Epistimologi sebagai sebuah Teori}

Istilah epistemologi berasal dari kata dalam bahasa Yunani yakni episteme yang berarti pengetahuan dan logos yang berarti perkataan, pikiran, dan ilmu. Kata "episteme" dalam bahasa Yunani merupakan akar dari kata kerja epistamai yang artinya mendudukkan, menempatkan, atau meletakkan. Maka, secara harfiah episteme berarti pengetahuan sebagai upaya intelektual untuk "menempatkan sesuatu dalam kedudukan setepatnya."

Selain kata "episteme", kata "pengetahuan" dalam bahasa Yunani juga dapat diganti dengan kata "gnosis", maka istilah "epistemologi" dalam sejarah pernah juga disebut gnoseologi. Sebagai kajian filosofis yang membuat telaah kritis dan analistis tentang dasar-dasar teoritis pengetahuan, epistemologi mendapat sebutan sebagai teori pengetahuan (theory of knowledge) (Sudarminta, 2002).

Epistemologi atau filsafat pengetahuan pada dasarnya merupakan suatu upaya rasional untuk menimbang dan menentukan nilai kognitif pengalaman manusia dalam interaksinya dengan diri, lingkungan sosial, dan alam sekitarnya. Maka, epistemologi adalah suatu disiplin ilmu yang bersifat evaluatif, normatif, dan kritis (Sudarminta, 2002).

Evaluatif diartikan menilai, apakah pernyataan, keyakinan, ataupun teori pengetahuan dapat dijamin kebenarannya serta dapat dipertanggungjawabkan. Normatif berarti norma atau tolak ukur, dalam hal ini tolak ukur penalaran bagi kebenaran pengetahuan. Epistemologi sebagai cabang ilmu filsafat tidak cukup hanya memberikan deskripsi atau paparan tentang bagaimana proses manusia mengetahui itu terjadi, tetapi perlu membuat penentuan mana yang betul dan mana yang keliru berdasarkan norma epistemik. Kritis bisa diartikan bagaimana cara kerja atau hasil yang telah dicapai dalam kegiatan, pendekatan mana yang diambil, ataupun kesimpulan yang diambil (Sudarminta, 2002). 
Perkembangan Kajian Komunikasi Pemasaran

Komunikasi pemasaran muncul sebagai suatu bentuk komunikasi yang lebih kompleks dan berbeda daripada sekedar promosi dan periklanan. Pada akhirnya, banyak akademisi dan juga praktisi mendefinisikan komunikasi pemasaran sebagai elemen-elemen promosi dari marketing mix yang melibatkan komunikasi antarorganisasi dan target audience pada segala bentuknya yang ditujukan untuk tujuan performance pemasaran (Prisgunanto, 2006, h.8).

Kegiatan komunikasi pemasaran merupakan rangkaian kegiatan untuk mewujudkan suatu produk, jasa, ide, dengan menggunakan bauran pemasaran (promotion mix) yaitu iklan (advertising), penjualan tatap muka (personal selling), promosi penjualan (sales promotion), hubungan masyarakat dan publisitas (public relation and publicity) serta pemasaran langsung (direct marketing) (Purba, dkk, 2006).

Komunikasi pemasaran meliputi tiga tujuan utama, yaitu untuk menyebarkan informasi (komunikasi informatif), mempengaruhi untuk melakukan pembelian atau menarik konsumen (komunikasi persuasif), dan mengingatkan khalayak umum untuk melakukan pembelian ulang (komunikasi mengingatkan kembali).

\section{METODE PENELITIAN}

Penelitian ini menggunakan paradigma interpretatif yakni paradigma yang bersifat analisis secara mendalam yang menekankan pada hubungan antara peneliti, teori dengan realitas.
Penelitian ini menggunakan kajian hermeunetika sebagai metode yang berkaitan dengan paradigma interpretatif. Hermeunetika berasal dari penelitian religius dan sastra bahasa tekstial dengan penyelidikan mendalam mengenai teks dan hubungan bagianbagiannya kepada keseluruhan dan dapat mengungkapkan makna secara yang lebih mendalam (Neuman, 2013).

Penelitian ini menggunakan hermeunetika karena peneliti melakukan pembacaan secara mendalam terhadap teks yang terdapat pada skripsi komunikasi pemasaran mahasiswa ilmu komunikasi pada tiga universitas melalui kategori teori yang digunakan.

Berdasarkan paradigma yang telah disebutkan, maka metode penelitian yang digunakan dalam penelitian ini adalah metode kualitatif. Jenis penelitian yang digunakan dalam penelitian ini adalah meta analisis. Neuman (2013) menjelaskan bahwa meta analisis adalah tekhnik khusus yang dibuat untuk membuat tinjauan integratif atau tinjauan metodologi. Meta analisis melibatkan pengumpulan rincian mengenai berbagai penelitian sebelumnya dan menyatukan hasilnya.

Sumber data dari penelitian ini adalah skripsi mengenai kajian komunikasi pemasaran mahasiswa ilmu komunikasi pada Universitas Brawijaya, Universitas Muhammadiyah Malang, dan Universitas Merdeka Malang periode tahun 2014-2018. Skripsi yang menjadi sumber data dalam penelitian ini memiliki kriteria sebagai berikut:

1. Skripsi yang memiliki salah satu keyword mengenai komunikasi pemasaran atau marketing 
communication, iklan atau advertising, personal selling, sales promotion, dan dirrect marketing.

2. Skripsi sudah terdapat pada perpustakaan Universitas Brawijaya, perpustakaan Universitas Muhammadiyah Malang, dan perpustakaan Universitas Merdeka Malang.

3. Skripsi dikerjakan oleh mahasiswa ilmu komunikasi Universitas Brawijaya, Universitas Muhammadiyah Malang, dan Universitas Merdeka Malang pada periode tahun 20142018.

Dalam penelitian ini, data diperoleh dari dokumentasi dengan menganalisis skripsi kajian komunikasi pemasaran yang dikerjakan mahasiswa komunikasi Universitas Brawijaya, Universitas Muhammadiyah Malang, dan Universitas Merdeka Malang pada tahun 2014-2018.

\section{HASIL DAN PEMBAHASAN}

Skripsi yang menjadi objek dalam penelitian ini berupa skripsi-skripsi mahasiswa ilmu komunikasi pada Fakultas Ilmu Sosial dan Ilmu Politik Universitas Brawijaya, Fakultas Ilmu Sosial dan Ilmu Politik Universitas Muhammadiyah Malang, dan Fakultas Ilmu Sosial dan Ilmu Politik Universitas Merdeka dengan tema Komunikasi Pemasaran. Berdasarkan analisis skripsi penelitian bidang komunikasi pemasaran di Fakultas Ilmu Sosial dan Ilmu Politik Universitas Brawijaya tahun 2014-2018 oleh peneliti diperoleh hasil sebanyak 107 skripsi, sementara
Fakultas Ilmu Sosial dan Ilmu Politik Universitas Muhammadiyah Malang tahun 2014-2018 diperoleh hasil sebanyak 108 skripsi, dan Fakultas Ilmu Sosial dan Ilmu Politik Universitas Merdeka tahun 2014-2018 diperoleh hasil sebanyak 15 skripsi.

\section{Rujukan Teori pada Universitas Brawijaya}

Berdasarkan fokus sub kategori bidang studi yang diteliti, ditemukan 59 skripsi dengan bidang komunikasi pemasaran, 26 skripsi dengan bidang advertising, 8 skripsi dengan bidang sales promotion, 6 skripsi dengan bidang direct marketing, dan 8 skripsi personal selling. Total skripsi komunikasi pemasaran pada Universitas Brawijaya berjumlah 107 skripsi.

Hasil penelitian menunjukkan bahwa dari keseluruhan total 107 skripsi kajian komunikasi pemasaran oleh mahasiswa Ilmu Komunikasi di Universitas Brawijaya, hanya sebagian yang memadukan dengan teori ataupun konsep tentang ilmu komunikasi. Penggunaan teori Elaboration Likelihood Model (ELM) paling dominan digunakan dalam skripsi kajian komunikasi pemasaran yakni sebanyak 13 skripsi, teori penyusunan pesan, personal branding, teori SOR, new media, reception analysis, dan teori persepsi masing-masing dua skripsi serta konsep komunikasi citra kota, teori habituasi dan tedium, aspek manajemen handling, teori Computer Mediated Communication, teori behaviorisme, teori atribusi, komunikasi persuasif, komunikasi pemasaran politik, conversation analysis ditemukan masing-masing satu skripsi. Selain teori dan konsep dalam 
ilmu komunikasi, teori dan konsep ilmu pemasaran masih banyak ditemukan dalam skripsi-skripsi pada mahasiswa ilmu komunikasi di Universitas Brawijaya.

\section{Rujukan Teori pada Universitas Muhammadiyah Malang}

Hasil penelitian pada Universitas Muhammadiyah Malang menunjukkan bahwa dari total 108 skripsi yang dibagi menjadi 75 skripsi dengan tema komunikasi pemasaran, 9 skripsi dengan tema advertising, 22 skripsi dengan tema sales promotion, 1 skripsi dengan tema direct marketing, dan 1 skripsi dengan tema personal selling, hanya sebagian yang memadukan dengan teori ataupun konsep tentang ilmu komunikasi.

Teori difusi dan inovasi serta teori SOR (Stimulus Organisme Response) merupakan teori komunikasi yang paling banyak digunakan dalam skripsi yakni komunikasi pemasaran yakni masing-masing tiga skripsi. teori kredibilitas sumber, keperkasaan efek, dan two ways asymmetric model digunakan pada masing-masing dua skripsi. Selanjutnya, teori encoding decoding, teori efek media, teori komunikasi promosi, teori reasoned action, teori motivasi, teori Individual differences, teori computer mediated communication, three ways effect strategy, impression management, teori co-orientation, teori pemaknaan, teori persepsi, teori one way communication, dan teori jarum hipordemik masingmasing digunakan dalam satu skripsi.

\section{Rujukan Teori pada Universitas Merdeka Malang}

Berdasarkan data di lapangan, ditemukan 14 skripsi dengan tema komunikasi pemasaran pada Universitas Merdeka Malang. 14 skripsi tersebut dibagi menjadi 8 skripsi dengan tema komunikasi pemasaran, 3 skripsi dengan tema advertising, 3 skripsi dengan tema sales promotion, dan tidak ada satupun skripsi yang membahas mengenai direct marketing dan personal selling.

Dari keseluruhan skripsi yang ditemukan hanya terdapat dua skripsi yang menggunakan teori ilmu komunikasi. Teori yang digunakan yakni teori persepsi dan teori dependensi media. Sementara sisanya dikerjakan dengan merujuk pada teori dan konsep yang ada dalam ranah ilmu pemasaran.

Berdasarkan data yang didapatkan dalam penelitian pada tiga universitas di kota Malang, teori yang paling banyak digunakan pada skripsi dengan tema komunikasi pemasaran adalah teori teori Elaboration Likelihood Model (ELM). Richard Petty dan John Cacioppo adalah psikolog sosial yang mengembangkan teori ini.

Jika dilihat dari aspek epistemologis, ELM adalah sebuah teori yang mencoba menjelaskan individu dalam mengevaluasi pesan yang diterima.

Elaboration Likelihood Model menjelaskan bahwa sikap bisa dibentuk secara permanen atau temporer tergantung pada alur pengolahan pesan pada individu penerima pesan.

Sikap permanen dihasilkan dari proses yang melibatkan motivasi, kemampuan dan kesempatan untuk melakukan elaborasi terhadap isi pesan persuasi, dalam arti individu menilai sebuah pesan secara mendalam, hati-hati dan dengan pemikiran yang 
kritis. Sedangkan sikap yang temporer terjadi ketika motivasi, kesempatan dan kemampuan mengelaborasi isi pesan rendah atau tidak ada sama sekali sehingga individu menilai pesan dengan sambil lalu saja tanpa mempertimbangkan argumen yang mendasari isi pesan tersebut.

Teori ELM mempengaruhi pemikiran-pemikiran yang kemudian mengantarkan kepada penerimaan atau penolakan terhadap pesan yang disampaikan kepada komunikan. Sejauh mana individu akan berpikir, tergantung pada seberapa penting isi pesan bagi individu tersebut.

Ontologi dalam ilmu komunikasi berpusat pada sifat interaksi sosial antar manusia (Littlejohn \& Foss, 2011). Jika dilihat dari aspek ontologi, teori Elaboration Likelihood Model ialah model komunikasi persuasif untuk menunjukkan dan menjelaskan perilaku komunikasi manusia dalam berbagai bentuk dengan pendekata komunikasi persuasi, khususnya tentang bagaimana peranan komunikator untuk mempersuasi dan merubah perilaku individu yang dituju dengan cara memahami keadaan dan sifat individu tersebut.

Penggunaan serta pengkajian teori komunikasi sendiri masih sangat sedikit dalam bidang komunikasi pemasaran. Melalui penelitian ini, ditemukan masih banyak penelitian yang hanya menggunakan konsep yang ada dalam bidang komunikasi pemasaran tanpa mengaitkannya dengan teori yang ada dalam bidang ilmu komunikasi itu sendiri. Padahal konsep sendiri hanya merupakan unit mendasar dari teori, yakni berupa ide yang dapat diungkapkan sebagai simbol atau dalam kata-kata (Neuman, 2013). Konsep berasal dari ide dalam kehidupan sehari-hari, pengalaman pribadi, pemikiran kreatif, atau observasi sehari-hari.

Seseorang menguraikan ide tersebut, memberikan definisi, dan kemudian pihak lain membahas ide tersebut mencoba memperjelas dan membuatnya lebih tepat. Orang mengembangkan konsep baru dari kontemplasi mendalam dan pikiran reflektif, terkadang setelah menyelidiki penemuan dalam studi penelitian atau dengan menyatukan temuan dan ide dari berbagai situasi yang berbeda. Peneliti menggunakan konsep untuk untuk membahas, menganalisis dan menelaah dunia sosial di sekitarnya (Neuman, 2013)

Berdasarkan aspek aksiologi, teori Elaboration Likelihood Model dapat dibuktikan melalui kajian dalam perilaku individu setelah diberikan terpaan pesan oleh komunikator. Aksiologi merupakan cabang filosofi yang berhubungan dengan penelitian tenang nilai-nilai (Litlejohn \& Foss, 2001). Terdapat dua rute untuk pengolahan informasi dalam teori ELM yaitu rute sentral dan rute periferal (Litlejohn \& Foss, 2001). Kedua rute tersebut sangat bermanfaat dan mendukung proses komunikasi persuasif. Rute sentral terjadi jika perilaku dasar dari individu dalam proses komunikasi melibatkan motivasi yang tinggi serta memiliki pemikiran yang aktif dan kritis terhadap pesan. Sehingga individu yang berada pada rute sentral akan lebih mudah dipersuasi dan dipengaruhi perilakunya daam jangka waktu yang lama. Rute periferal terjadi saat individu cenderung mengolah pesan dengan motivasi yang rendah dan pemikiran kurang kritis, perubahan apapun yang terjadi pada diri individu penerima pesan mungkin 
hanya akan bertahan sementara dan kurang berpengaruh pada bagaimana individu bertindak dalam jangka panjang.

\section{PENUTUP}

\section{Simpulan}

Rujukan teori komunikasi yang paling banyak digunakan pada skripsi dengan tema komunikasi pemasaran pada tiga universitas adalah teori Elaboration Likelihood Model. Masih banyak ditemukan skripsi pada bidang kajian komunikasi pemasaran yang belum mengaplikasikan penggunaan teori komunikasi ke dalam skripsi yang dikerjakan. Dari tiga universitas yang diteliti ditemukan bahwa sebagian besar skripsi lebih menitikberatkan pada penggunaan konsep yang ada dalam bidang pemasaran.

\section{Saran}

Mengingat
memetakan kentingnya
pemasaran bagi perkembangan ilmu
komunikasi, maka r peneliti
menyarankan dilakukan penelitian
perbandingan corak komunikasi
pemasaran Universitas yang ada di kota
Malang dengan Universitas lainnya di
kota lain di Indonesia, semisal
universitas Padjajaran atau Universitas
Indonesia. Peneliti juga menyarankan
untuk melakukan penelitian meta
analisis terhadap bidang kajian
pemasaran dengan isu potensial yang
masih belum banyak diteliti yakni
mengenai ekonomi media.

\section{DAFTAR PUSTAKA}

Arneson, P. (2007). perspective on philosophy of communication. Purdue University.
Effendy, O. U. (2003). Ilmu, Teori, dan Filsafat Komunikasi. Bandung: Citra Aditya Bakti.

Hermawan. (2012). Komunikasi Pemasaran. Jakarta: Erlangga.

Kennedy, J. E., \& Soemanagara, R. (2006). Marketing Communication. Jakarta: PT Buana Ilmu Populer.

Kriyantono, R. (2014). Sinergi Lokal \& Barat dalam Teori dan Praktik Komunikasi. Jakarta: Prenada Media.

Littlejohn, S., \& Foss, K. (2012). Teori Komunikasi. Jakarta: Salemba Humanika.

Neuman, W. L. (2013). Metode Penelitian Sosial : Pendekatan Kualitatif dan Kuantitatif Edisi 7. Jakarta: Index.

Prisgunanto, I. (2006). Komunikasi pemasaran, Strategi, dan Taktik. Jakarta: Ghalia Indonesia.

Sudarminta. (2002). Epistimologi Dasar PengantarFilsafat Pengetahuan. Yogyakarta: Kanisius.

Tjiptono. (2008). strategi pemasaran. Yogyakarta: Andi Offset. 